\title{
Estimating Angstrom-Prescott Coefficients for India and Developing a Correlation between Sunshine Hours and Global Solar Radiation for India
}

\author{
R. C. Srivastava and Harsha Pandey \\ Department of Mathematics and Statistics, D. D. U. Gorakhpur University, Gorakhpur 273009, India \\ Correspondence should be addressed to Harsha Pandey; harsha_pande@yahoo.com
}

Received 21 June 2013; Accepted 16 July 2013

Academic Editors: B. Mwinyiwiwa and A. Stoppato

Copyright (c) 2013 R. C. Srivastava and H. Pandey. This is an open access article distributed under the Creative Commons Attribution License, which permits unrestricted use, distribution, and reproduction in any medium, provided the original work is properly cited.

\begin{abstract}
The amount of solar energy that reaches the earth in one hour is sufficient to supply the world's energy needs for one year. Harvesting this energy efficiently is a huge challenge. In most countries including India, the number of observing stations is inadequate. Therefore, it is essential that some reliable mathematical models be developed to estimate the solar radiation for places where measurements are not carried out and for places where measurement records are not available. In this paper, Angstrom-Prescott model parameters are estimated for seven different sites in India, and a correlation is developed for India, which is found to be a good fit. Also a correlation is developed for predicting the solar radiation using only sunshine hour data.
\end{abstract}

\section{Introduction}

Solar radiation which we receive as heat and light can be converted to useful thermal energy or can be used for production of electricity by using solar photovoltaic cells or solar thermal power. Availability of reliable solar radiation data is vital for the success of solar energy installations in different sites of the country.

The kind of solar radiation data required depends on application and user. For example, monthly or daily averaged data are required for climatologic studies or to conduct feasibility studies for solar energy systems. Data for hourly (or shorter) periods are needed to simulate the performance of solar devices or during collector testing and other activities [1].

Knowledge of the local solar radiation is essential for the proper design of building energy systems, solar energy systems, and a good evaluation of thermal environment within buildings [2-7].

Systematic measurements of diffuse solar energy and the global (total) irradiation incident on a horizontal surface are usually undertaken by a national agency, which is the national meteorological office in many countries. There is a relative abundance of sunshine duration data, and therefore it is a common practice to correlate the solar radiation with sunshine duration measurements.

\section{Materials and Methods}

In practical studies it is logical to consider that the solar radiation is directly proportional to the sunshine duration. The formulation of the proportionality can be derived from the measurements of the variables through scatter diagrams and most often by the application of statistical regression methods. The original models in solar energy expressed this relationship between solar radiation and the sunshine duration as linear. Such a pioneering relationship was presented by Angström in 1924 [8].

2.1. Angstrom Model. The original Angstrom-type regression equation related monthly average daily radiation to clear day radiation in a given location and average fraction of possible sunshine hours:

$$
\frac{H}{H_{c}}=a+b \frac{n}{N}
$$


TABLE 1: Estimated angles of declination for various months in a year.

\begin{tabular}{|c|c|c|c|c|}
\hline \multirow[b]{2}{*}{ Month } & \multirow{2}{*}{$\begin{array}{l}\mathrm{d} \text { for } i \text { th day } \\
\text { of the month }\end{array}$} & \multicolumn{3}{|c|}{ For the average day of the month } \\
\hline & & Date & $\begin{array}{c}\mathrm{d} \text {, day of the } \\
\text { year }\end{array}$ & $\begin{array}{l}\delta \text {, angle of } \\
\text { declination }\end{array}$ \\
\hline January & $i$ & 17 & 17 & -20.9 \\
\hline February & $31+i$ & 16 & 47 & -13.0 \\
\hline March & $59+i$ & 16 & 75 & -2.4 \\
\hline April & $90+i$ & 15 & 105 & 9.4 \\
\hline May & $120+i$ & 15 & 135 & 18.8 \\
\hline June & $151+i$ & 11 & 162 & 23.1 \\
\hline July & $181+i$ & 17 & 198 & 21.2 \\
\hline August & $212+i$ & 16 & 228 & 13.5 \\
\hline September & $243+i$ & 15 & 258 & 2.2 \\
\hline October & $273+i$ & 15 & 288 & -9.6 \\
\hline November & $304+i$ & 14 & 318 & -18.9 \\
\hline December & $334+i$ & 10 & 344 & -23.0 \\
\hline
\end{tabular}

where $H=$ monthly average daily global radiation (Wh $/ \mathrm{m}^{2} /$ day), $H_{c}=$ monthly average clear sky daily global radiation for the location in a given day, $n=$ actual sunshine duration in a day, respectively, (hours), $N=$ monthly average maximum possible bright sunshine duration in a day and also known as monthly mean length of the day in hours, $a$ and $b=$ empirical coefficients. These coefficients are locationspecific coefficients referred to as fractions of extraterrestrial radiation on overcast days and on average days, respectively.

The ratio $n / N$ is referred to as cloudless index. It gives information about atmospheric characteristics and conditions of the study area.

2.2. Angstrom-Prescott Model. A basic difficulty with (1) lies in the definition of the terms $n / N$ and $H_{c}$. Because there may be problems in calculating clear sky radiation accurately, this model was modified by Prescott [9] in 1940 by replacing clear sky radiation with extraterrestrial radiation $H_{0}$. This model popularly known as the Angstrom-Prescott model is the most commonly used model and is given by

$$
\frac{H}{H_{0}}=a+b \frac{n}{N},
$$

where $H_{0}$ is the monthly average daily extraterrestrial radiation.

The ratio of solar radiation at the surface of the Earth $(H)$ to extraterrestrial radiation $\left(H_{0}\right)$, that is, $H / H_{0}$, is called the Clearness Index. Values of the monthly average daily extraterrestrial radiation $\left(H_{0}\right)$ is calculated from the following [10]:

$$
\begin{aligned}
H_{0}= & \frac{24 \times 3600 \times I_{\mathrm{sc}}}{\pi} \times\left[1+0.033 \cos \left(\frac{360 \times d}{365}\right)\right] \\
& \times\left[\cos \phi \cos \delta \sin \omega+\frac{\pi w}{180} \sin \phi \sin \delta\right],
\end{aligned}
$$

TABLE 2: Location of the selected meteorological stations [19].

\begin{tabular}{lccc}
\hline $\begin{array}{l}\text { Meteorological } \\
\text { station }\end{array}$ & Latitude $\left({ }^{\circ} \mathrm{N}\right)$ & Longitude $\left({ }^{\circ} \mathrm{E}\right)$ & Altitude $(\mathrm{m})$ \\
\hline New Delhi & $28^{\circ} 39^{\prime} 42^{\prime \prime}$ & $77^{\circ} 18^{\prime} 32^{\prime \prime}$ & 207 \\
Jaipur & $25^{\circ} 23^{\prime} 02^{\prime \prime}$ & $72^{\circ} 30^{\prime} 32^{\prime \prime}$ & 269 \\
Kolkata & $22^{\circ} 34^{\prime} 11^{\prime \prime}$ & $88^{\circ} 22^{\prime} 11^{\prime \prime}$ & 12 \\
Jodhpur & $26^{\circ} 18^{\prime} 00^{\prime \prime}$ & $73^{\circ} 01^{\prime} 00^{\prime \prime}$ & 224 \\
Mumbai & $18^{\circ} 58^{\prime} 30^{\prime \prime}$ & $72^{\circ} 49^{\prime} 33^{\prime \prime}$ & 27 \\
Ahmedabad & $23^{\circ} 2^{\prime} 00^{\prime \prime}$ & $72^{\circ} 35^{\prime} 00^{\prime \prime}$ & 53 \\
Pune & $18^{\circ} 32^{\prime} 00^{\prime \prime}$ & $73^{\circ} 52^{\prime} 00^{\prime \prime}$ & 560 \\
\hline
\end{tabular}

where $I_{\text {sc }}=$ solar constant with a value of $1367 \mathrm{Wm}^{-2}, d=$ day of the year from January 1 to December 31 taking January 1st as $1, \phi=$ latitude of the location, $\delta=$ declination angle, $\omega=$ sunset hour angle, and $\omega=$ $\cos ^{-1}(-\tan \phi \tan \delta)$.

Declination angle can be obtained by the equation given by Cooper in 1969 [11]:

$$
\delta=23.45 \sin \left[360\left(\frac{284+d}{365}\right)\right] .
$$

Klein [12] in 1977 recommended average days of the various months and corresponding angle of declination as in Table 1.

The maximum possible sunshine duration $N$ (hours) for a horizontal surface is given by

$$
N=\frac{2 w}{15} .
$$

Many authors like Fritz and MacDonald [13], Black et al. [14], Mateer [15], and Samuel [16] estimated the values of " $a$ " and " $b$ " for different sites.

2.2.1. Estimating Parameters of Angstrom-Prescott Model for Different Sites in India Using Monthly Radiation Values. India is situated at the north of the equator between $8^{\circ} 4^{\prime}$ and $37^{\circ} 6^{\prime}$ north latitude and $68^{\circ} 7^{\prime}$ and $97^{\circ} 25^{\prime}$ east longitude [17]. In order to determine the value of $H$ in (2) for India, sunshine hours data recorded over the period 1986-2000 are used for seven selected meteorological stations, namely, New Delhi, Jaipur, Kolkata, Jodhpur, Mumbai, Ahemdabad, and Pune [18]. Meteorological parameters for these locations are listed in Table 2.

In this work values of $H_{0}$ and $N$ are calculated for each month using (3) and (5), respectively. A regression line is fit between $H / H_{0}$ and $n / N$ using scatter diagram (see Figures $1,2,3,4,5,6,7,8,9,10,11,12,13$, and 14). The regression coefficients of the plotted line are the parameters " $a$ " and " $b$ " of the Angstrom-Prescott model. Here " $a$ " is the intercept on the $H / H_{0}$ axis and " $b$ " is the slope of the regression line. Results obtained are given in Table 3.

\subsubsection{Estimates of Annual Global Radiation for Different} Stations in India. Regression equations obtained previously for different meteorological stations are calculated using monthly average of daily solar radiation and sunshine data. 
TABLE 3: Regression lines for selected meteorological stations in India.

\begin{tabular}{lc}
\hline Meteorological station & Angstrom-Prescott model \\
\hline New Delhi & $H / H_{0}=0.6043+0.131(n / N)$ \\
Jodhpur & $H / H_{0}=0.1257+0.6002(n / N)$ \\
Jaipur & $H / H_{0}=0.3359+0.3328(n / N)$ \\
Ahemedabad & $H / H_{0}=0.1212+0.5822(n / N)$ \\
Mumbai & $H / H_{0}=0.1053+0.5698(n / N)$ \\
Kolkata & $H / H_{0}=0.0518+0.6443(n / N)$ \\
Pune & $H / H_{0}=0.0937+0.6315(n / N)$ \\
\hline
\end{tabular}

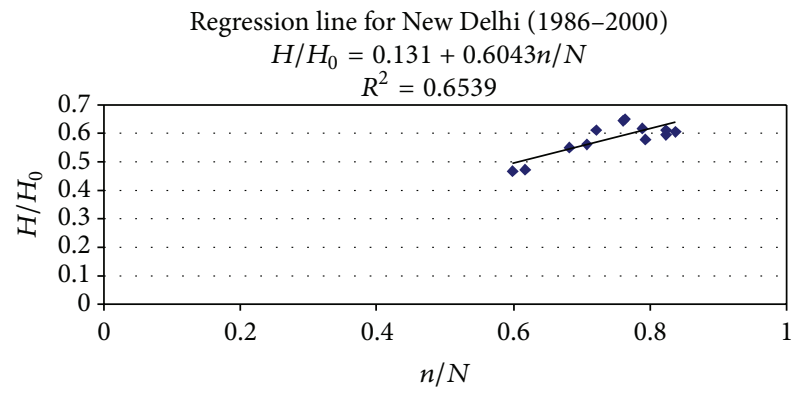

Figure 1

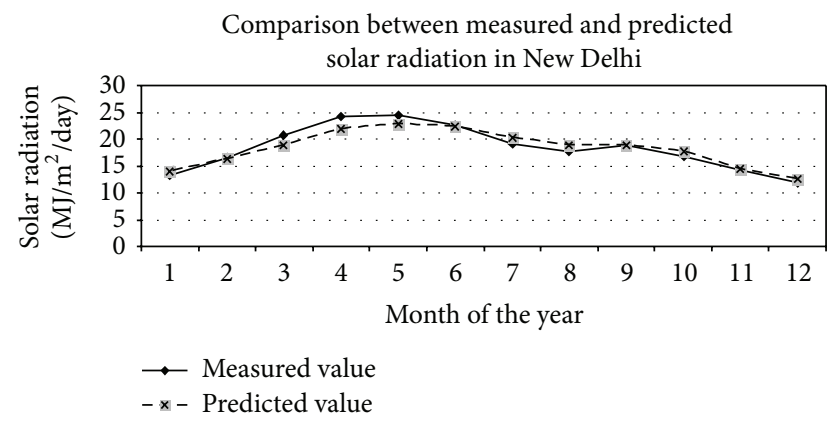

FIgURE 2

It is validated by evaluating the annual solar radiation for the same meteorological stations and comparing them with measured values of solar radiations for these stations. Table 4 shows estimates of annual global solar radiation for selected meteorological stations in India.

Observing Table 4 we find a good agreement between measured and predicted values. Plotting them on the same graph we obtained Figure 15 which shows the same.

\subsubsection{Correlation between Sunshine Hours and Global Solar} Radiation in India. Using the average of the correlation obtained in Table 4, we get the Angstrom-Prescott model for India as

$$
\frac{H}{H_{0}}=0.1382+0.5564 \frac{n}{N} .
$$

2.2.4. Comparison Techniques. Differences between estimated and measured values of solar radiation are determined

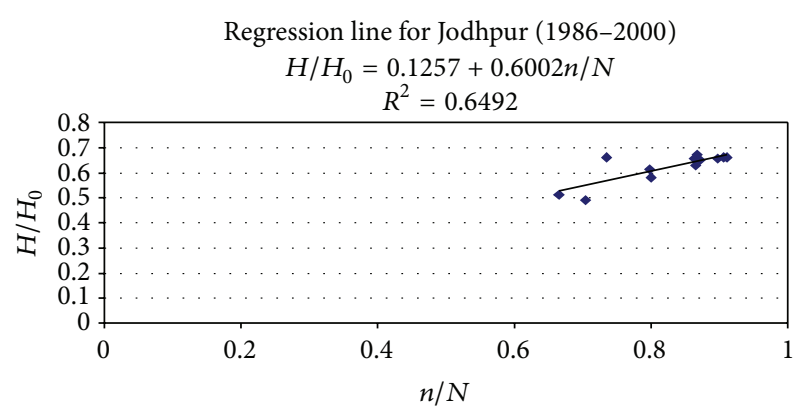

Figure 3

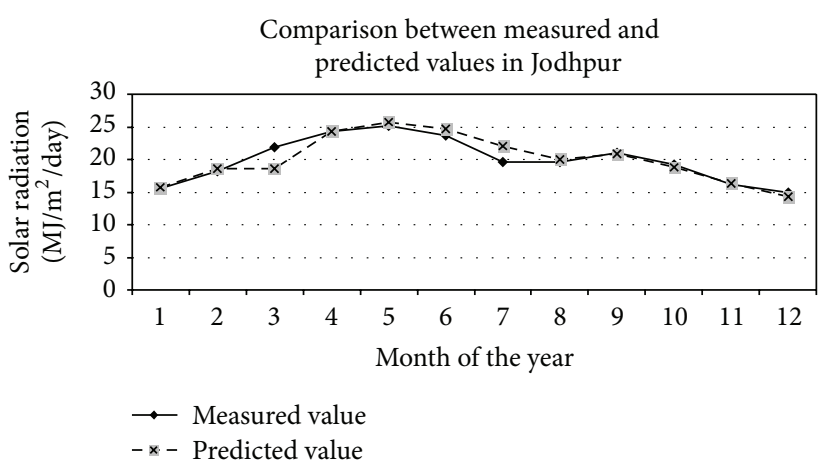

FIGURE 4

by the Mean Bias Error (MBE), the Root Mean Square Error (RMSE), and the Mean Percentage Error (MPE), given by the following respective expressions:

$$
\begin{gathered}
\mathrm{MBE}=\frac{\sum\left(H_{\mathrm{cal}}-H_{\text {meas }}\right)}{n}, \\
\mathrm{RMSE}=\sqrt{\frac{\sum\left(H_{\text {cal }}-H_{\text {meas }}\right)^{2}}{n},} \\
\mathrm{MPE}=\frac{1}{n} \sum \frac{H_{\text {cal }}-H_{\text {meas }}}{H_{\text {meas }}} \times 100,
\end{gathered}
$$

where $n$ is the number of data pairs.

Values of regression constants, the correlation coefficients " $R$," and the values of the MBE, RMSE, and MPE for the seven meteorological stations are summarized in Table 5.

2.3. Correlation between Parameter of the Angstrom-Prescott Model and Sunshine Ratio $n / N$. Since the number of meteorological stations is not adequate in India, even the places where these stations are available, many of them have no arrangement for measuring solar radiation. But comparatively it is easier to measure actual sunshine duration for different places, and therefore this data is more widely available across India. So if we have correlation that uses only sunshine hour data for calculating parameter of the Angstrom-Prescott model, then it will be possible to estimate solar radiation even for those places where solar radiation data is not available. 
TABLE 4: Estimates of annual global solar radiation for selected meteorological stations in India.

\begin{tabular}{|c|c|c|c|c|c|c|}
\hline Location & $\begin{array}{c}\text { Average annual } \\
n / N\end{array}$ & $a$ & $b$ & $a+b$ & $\begin{array}{l}\text { Annual } H_{\text {meas }} \\
\mathrm{MJ} \mathrm{m}^{-2} \text { day }^{-1}\end{array}$ & $\begin{array}{l}\text { Annual } H_{\mathrm{cal}} \\
\mathrm{MJ} \mathrm{m}^{-2} \text { day }^{-1}\end{array}$ \\
\hline Delhi & 0.74 & 0.1310 & 0.6043 & 0.7353 & 18.25 & 18.44 \\
\hline Jodhpur & 0.82 & 0.1257 & 0.6002 & 0.7259 & 19.97 & 20.09 \\
\hline Jaipur & 0.79 & 0.3359 & 0.3328 & 0.6687 & 19.42 & 19.62 \\
\hline Ahmedabad & 0.81 & 0.1212 & 0.5822 & 0.7034 & 19.30 & 19.56 \\
\hline Mumbai & 0.76 & 0.1053 & 0.5698 & 0.5751 & 18.25 & 18.40 \\
\hline Kolkata & 0.70 & 0.0518 & 0.6443 & 0.6951 & 16.17 & 16.48 \\
\hline Pune & 0.76 & 0.0963 & 0.6315 & 0.7252 & 19.51 & 19.80 \\
\hline Average & & 0.1382 & 0.5664 & 0.7046 & & \\
\hline
\end{tabular}

TABLE 5: Estimated values of Angstrom-Prescott parameters “ $a$," " $b$," the correlation coefficient " $R$," and the values of the MBE, RMSE, and MPE for the seven meteorological stations.

\begin{tabular}{|c|c|c|c|c|c|c|c|}
\hline \multirow{2}{*}{ Location } & \multirow{2}{*}{ Correlation coefficient $R$} & \multicolumn{3}{|c|}{ Estimated Angstrom-Prescott parameters } & \multirow{2}{*}{$\mathrm{MBE}$} & \multirow{2}{*}{ RMSE } & \multirow{2}{*}{ MPE \% } \\
\hline & & $a$ & $b$ & $a+b$ & & & \\
\hline Delhi & 0.81 & 0.1310 & 0.6043 & 0.7353 & -0.105 & 1.1243 & 0.3408 \\
\hline Jodhpur & 0.81 & 0.1257 & 0.6002 & 0.7259 & 0.0758 & 1.2166 & 0.3650 \\
\hline Jaipur & 0.51 & 0.3359 & 0.3328 & 0.6687 & -0.0583 & 2.1703 & 1.1058 \\
\hline Ahmedabad & 0.88 & 0.1212 & 0.5822 & 0.7034 & -0.0517 & 1.4768 & 0.7692 \\
\hline Mumbai & 0.91 & 0.1053 & 0.5698 & 0.5751 & -0.0517 & 1.4531 & 0.7100 \\
\hline Kolkata & 0.84 & 0.0518 & 0.6443 & 0.6951 & 0.0242 & 1.3019 & 0.0025 \\
\hline Pune & 0.96 & 0.0937 & 0.6315 & 0.7252 & 0.0092 & 0.7528 & 0.2058 \\
\hline
\end{tabular}

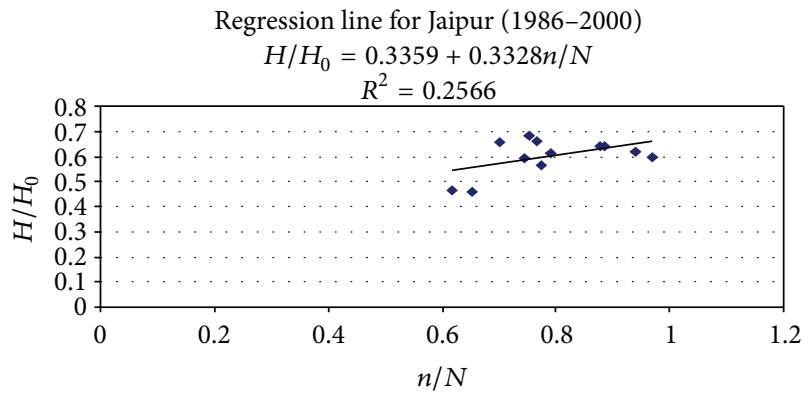

FIGURE 5

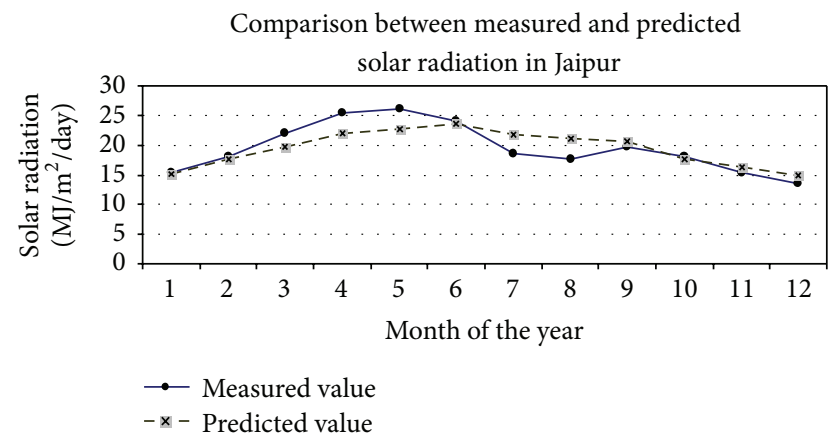

FIGURE 6

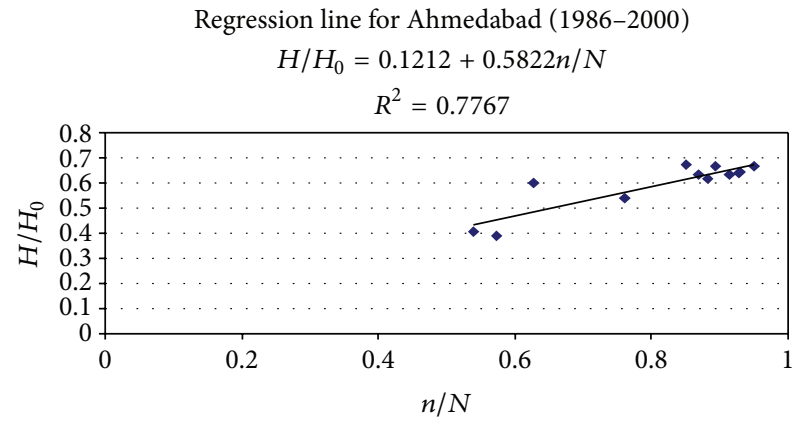

FIGURE 7

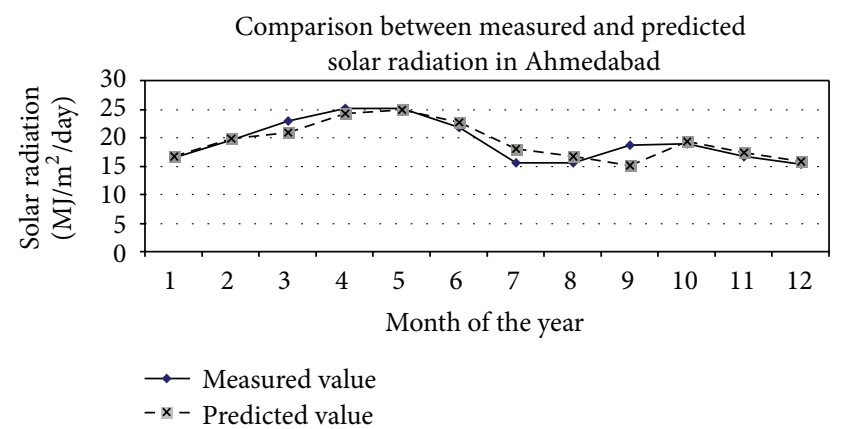

FigURE 8 


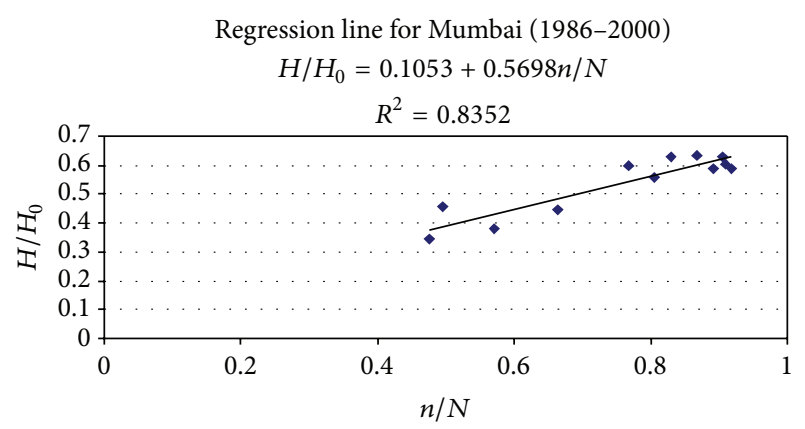

FIGURE 9

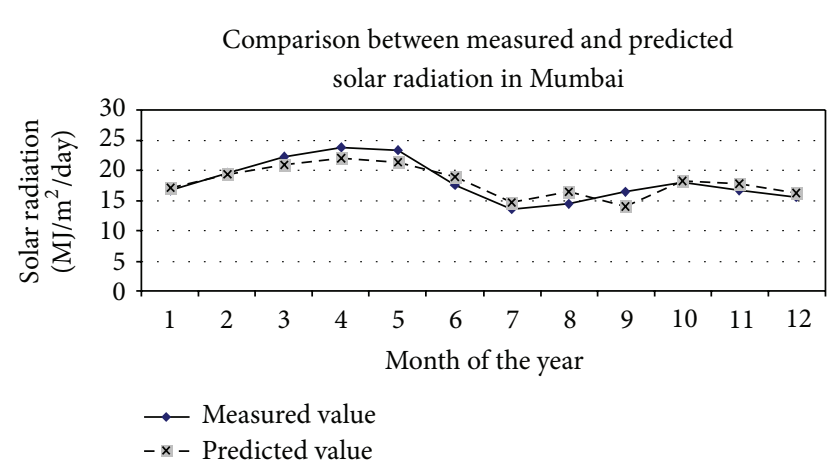

Figure 10

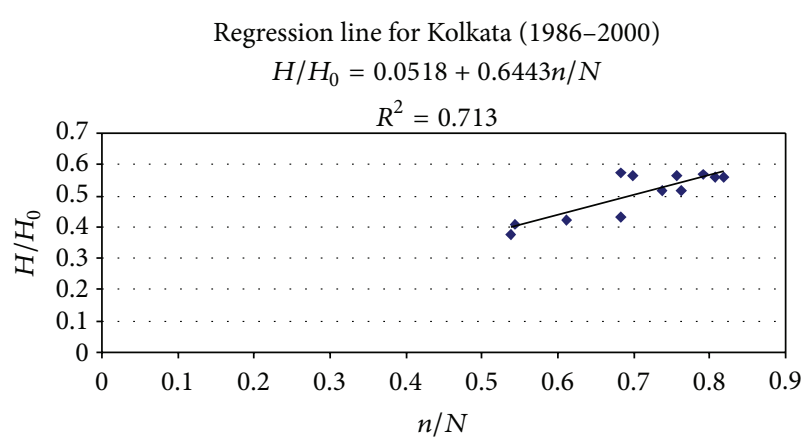

Figure 11

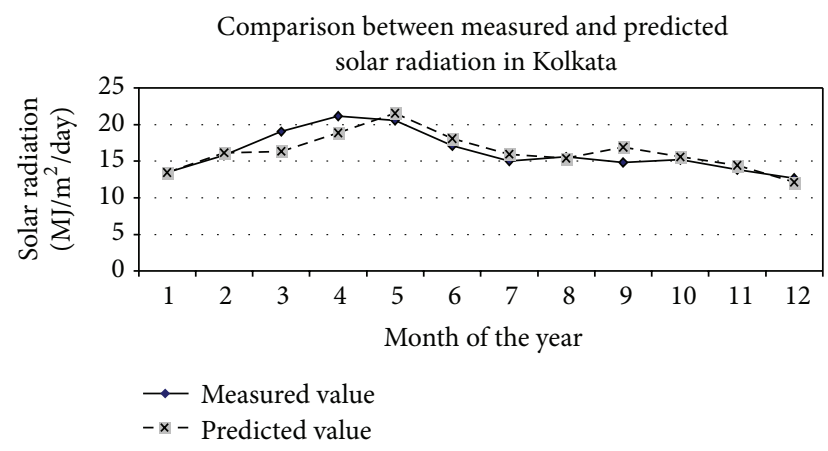

FIGURE 12

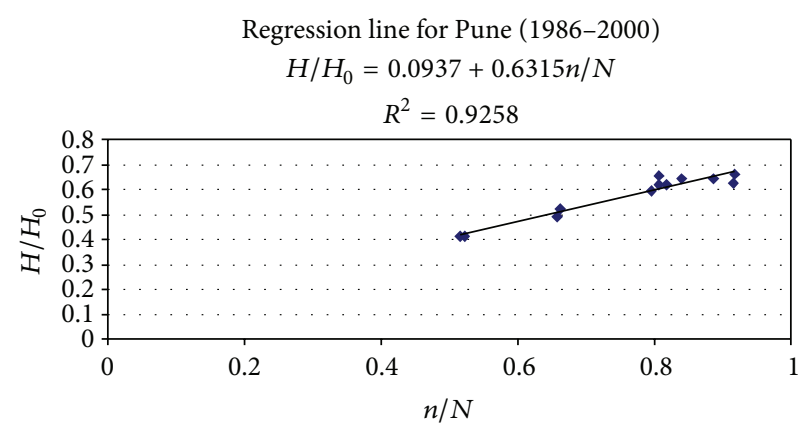

FIgURE 13

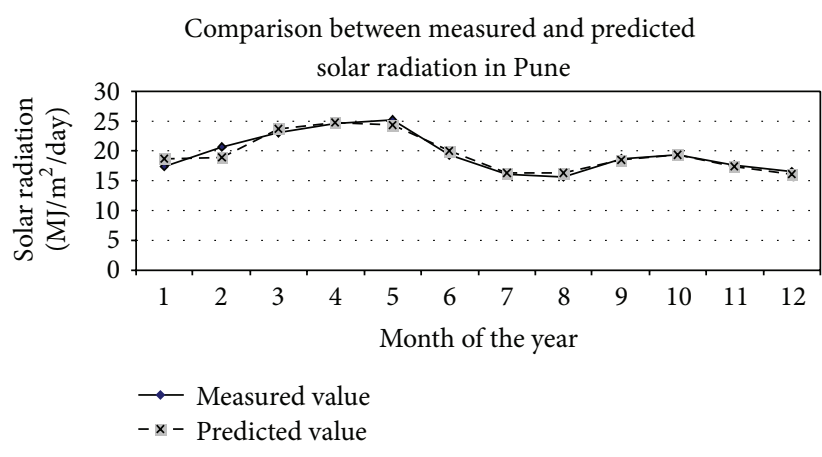

FIGURE 14

To obtain this correlation parabolic regression curve is fit between " $a$ " versus " $n / N$ " and " $b$ " versus " $n / N$ " data given in Table 4, and we obtained the following correlation equation for India (see Figures 16 and 17):

$$
\begin{aligned}
& a=-17.222\left(\frac{n}{N}\right)^{2}+27.18\left(\frac{n}{N}\right)-10.533, \\
& b=18.676\left(\frac{n}{N}\right)^{2}-29.395\left(\frac{n}{N}\right)+12.098 .
\end{aligned}
$$

The importance of this correlation lies in the fact that using this correlation solar radiation can be estimated for every location in India, even at the places where we do not have a system to measure solar radiation. Thus, coefficients of the Angstrom-Prescott model for India can be estimated using (8), even if only sunshine data is available.

\section{Results and Discussion}

Results of data analysis show that maximum solar radiation is observed in May and minimum solar radiation is observed in December.

The sum of the regression coefficients $(a+b)$ as shown in Table 4 is interpreted as the transmissivity of the atmosphere for global solar radiation under perfectly clear sky conditions [20]. A clear day means $n / N=1$, and then by (2)

$$
\frac{H}{H_{0}}=a+b
$$



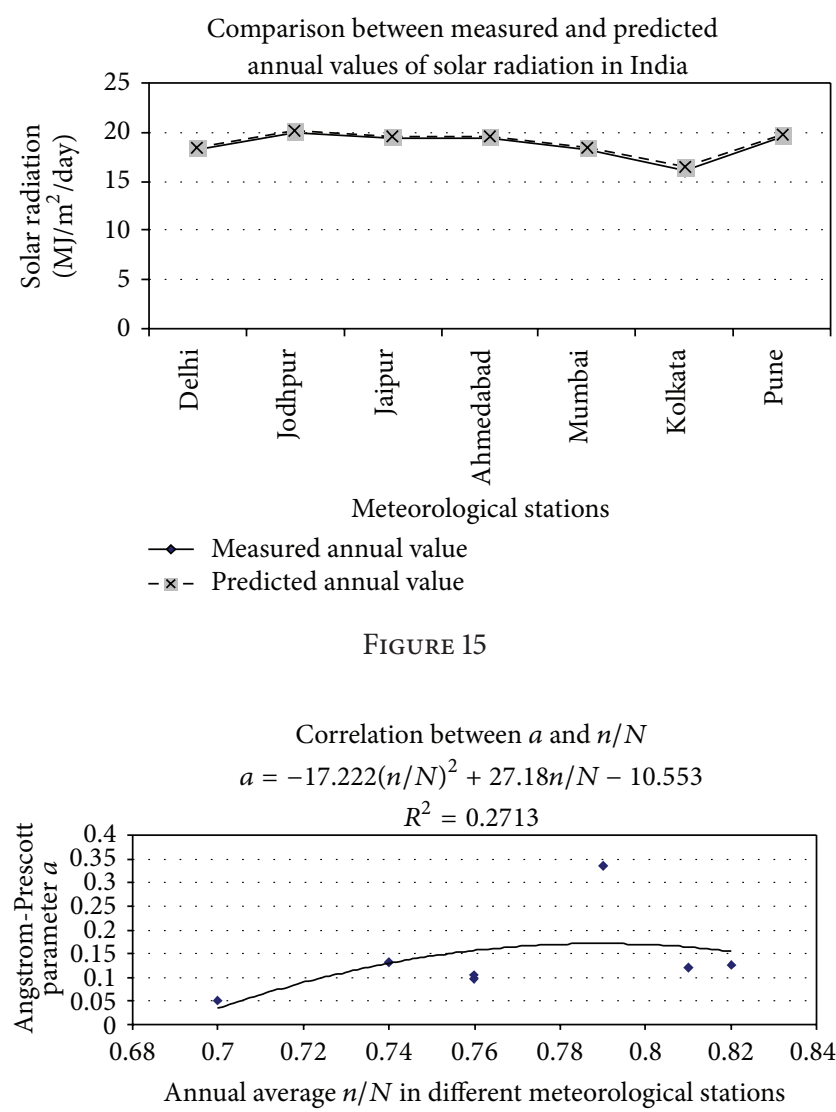

Figure 16

Also for a completely overcast day, $n / N=0$, which reduces (2) to the form

$$
\frac{H}{H_{0}}=a .
$$

Thus parameter " $a$ " can be interpreted as the transmissivity of an overcast atmosphere, which essentially accounts for the diffuse component.

It is obvious from Table 5 that neither " $a$ " nor " $b$ " varies with latitude or altitude in any systematic manner. However, the values of the sum of the regression constants $a+b$, which represent the maximum Clearness Index for $n / N=1$, are found to be almost equal for various meteorological stations.

The values of the regression constants $a$ and $b$ are in close agreement with those given for 101 locations in the paper of Martínez-Lozano et al. [21], ranging from 0.06 to 0.44 for " $a$ " and from 0.19 to 0.87 for " $b$."

It can be easily observed from the Table 5 that the values of correlation coefficients for different meteorological stations are more than 0.80 (except for Jaipur). It means a good fit between the Clearness Index $\mathrm{H} / \mathrm{H}_{0}$ and the relative possible number of sunshine hours $n / N$.

Also, analysing Table 4 it is found that there is a good agreement between the measured and calculated values of global radiation for the different meteorological station. It is further established by very low values of MBE, RMSE, and MPE as shown in Table 5. The percentage error is less than

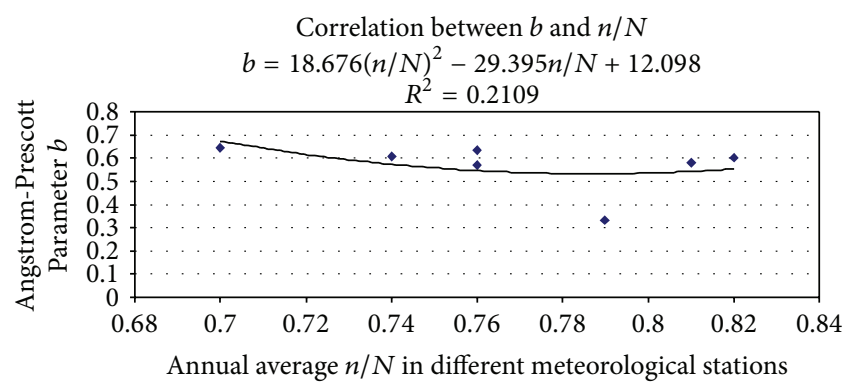

FIGURE 17

$\pm 2 \%$ at any of the meteorological stations. This suggests that the Angstrom-Prescott correlations model is a good model to estimate the solar radiation in India.

Table 3 gives the summary of the first-order AngstromPrescott correlations model that has been developed for use in estimating values of $H$ at each of the respective seven meteorological stations.

Also based on these results summarized in Tables 3, 4, and 5 a linear regression model for estimating solar radiation in India is developed, which comes out to be

$$
\frac{H}{H_{0}}=0.1382+0.5564 \frac{n}{N} \text {. }
$$

Also, a new parabolic correlation has been developed so that the coefficient of the Angstrom-Prescott models can be estimated even if only sunshine hour data is available;

$$
\begin{aligned}
& a=-17.222\left(\frac{n}{N}\right)^{2}+27.18\left(\frac{n}{N}\right)-10.533, \\
& b=18.676\left(\frac{n}{N}\right)^{2}-29.395\left(\frac{n}{N}\right)+12.098 .
\end{aligned}
$$

\section{Conclusion}

Energy is the primary requirement for development of any country. The world is heading towards energy crisis as fossil fuel reserves are depleting rapidly and demand for energy is increasing exponentially. Therefore, we need to exploit the widely available nonconventional energy resource "The Sun." Designing a solar system is crucial for fulfilling the energy requirement of the people. In this direction the knowledge of the amount of irradiance reaching any point on the Earth's surface is very essential.

The Angstrom-Prescott models that are developed in this study (see Table 3, (6), and (8)) may help the Indian Government to develop realistic energy policies and programmes based on sound scientific knowledge.

\section{References}

[1] B. Viorel, Modelling Solar Radiation at the Earth's Surface Recent Advances, chapter 1, Springer, Berlin, Germany, 2008.

[2] Z. Lu, R. H. Piedrahita, and C. Dos Santos Neto, "Generation of daily and hourly solar radiation values for modeling water quality in aquaculture ponds," Transactions of the American 
Society of Agricultural Engineers, vol. 41, no. 6, pp. 1853-1858, 1998.

[3] M. A. Machler and M. Iqbal, "A modification of the ASHRAE clear-sky irradiation model," ASHRAE Transactions, vol. 91, no. la, pp. 106-115, 1985.

[4] T. J. Cartwright, "Here comes the Sun: solar energy from a flat-plate collector," in Modelling the World in a SpreadsheetEnvironmental Simulation on a Microcomputer, pp. 121-144, The Johns Hopkins University Press, London, UK, 1993.

[5] J. H. Salazar Trujillo, "Solar performance and shadow behaviour in buildings-case study with computer modelling of a building in Loranca, Spain," Building and Environment, vol. 33, no. 2-3, pp. 117-130, 1998.

[6] ASHRAE Handbook: HVAC Applications, ASHRAE, Atlanta, Ga, USA, 1999.

[7] D. H. W. Li and J. C. Lam, "Solar heat gain factors and the implications to building designs in subtropical regions," Energy and Buildings, vol. 32, no. 1, pp. 47-55, 2000.

[8] A. Angström, "Solar terrestrial radiation," Quarterly Journal of the Royal Meteorological Society, vol. 50, pp. 121-126, 1924.

[9] J. A. Prescott, "Evaporation from water surface in relation to solar radiation," Transactions of The Royal Society of South Australia, vol. 40, pp. 114-118, 1940.

[10] J. A. Duffie and W. A. Beckman, Solar Engineering of Thermal Processing, John Wiley \& Sons, Madison, Wis, USA, 2nd edition, 1991.

[11] P. I. Cooper, "The absorption of radiation in solar stills," Solar Energy, vol. 12, no. 3, pp. 333-346, 1969.

[12] S. A. Klein, "Calculation of monthly average insolation on tilted surfaces," Solar Energy, vol. 19, no. 4, pp. 325-329, 1977.

[13] S. Fritz and T. H. MacDonald, "Average solar radiation in the United States," Heating Ventilating, vol. 46, pp. 61-64, 1949.

[14] J. N. Black, C. W. Bonython, and J. A. Prescott, "Solar radiation and duration of sunshine," Quarterly Journal of the Royal Meteorological Society, vol. 80, no. 344, pp. 231-235, 1954.

[15] C. L. Mateer, "A preliminary estimate of the average insolation in Canada," Canadian Journal of Agricultural Science, vol. 35, pp. 579-594, 1955.

[16] T. D. M. A. Samuel, "Estimation of global radiation for Sri Lanka," Solar Energy, vol. 47, no. 5, pp. 333-337, 1991.

[17] Compiled and edited by Research, Reference and Training Division, India Yearbook 2007, Publications Division, Ministry of Information \& Broadcasting, Government of India, 2007.

[18] Solar Radiation Hand Book, A joint Project of Solar Energy Centre, MNRE and Indian Metrological Department, 2008.

[19] India Meteorological Department Regional Instruments Maintenance Centre New Delhi, http://ddgmui.imd.gov.in/rimcnewdelhi/rimcawscontactdetails.php?opt=1.

[20] K. J. A. Revfeim, "An interpretation of the coefficients of the Angström equation," Solar Energy, vol. 31, no. 4, pp. 415-416, 1983.

[21] J. A. Martínez-Lozano, F. Tena, J. E. Onrubia, and J. De La Rubia, "The historical evolution of the Ångström formula and its modifications: review and bibliography," Agricultural and Forest Meteorology, vol. 33, no. 2-3, pp. 109-128, 1984. 


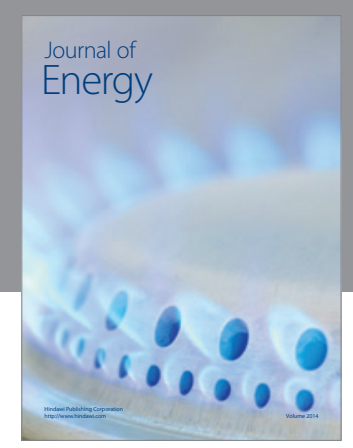

Journal of

Industrial Engineering
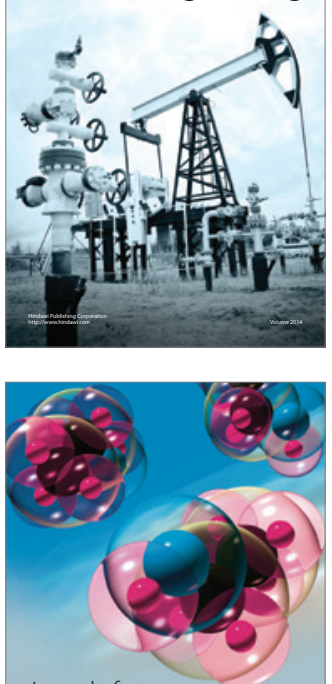

Fuels
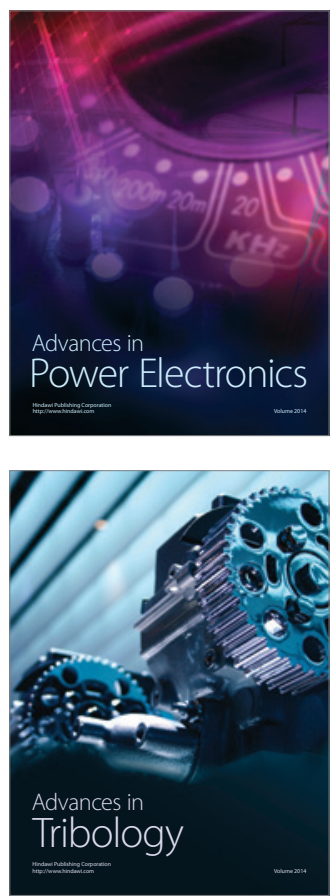

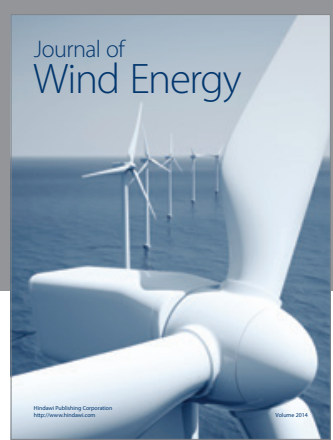

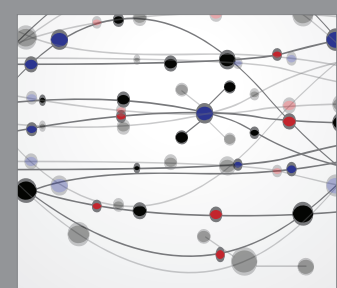

The Scientific World Journal

Submit your manuscripts at http://www.hindawi.com

Journal of

Structures
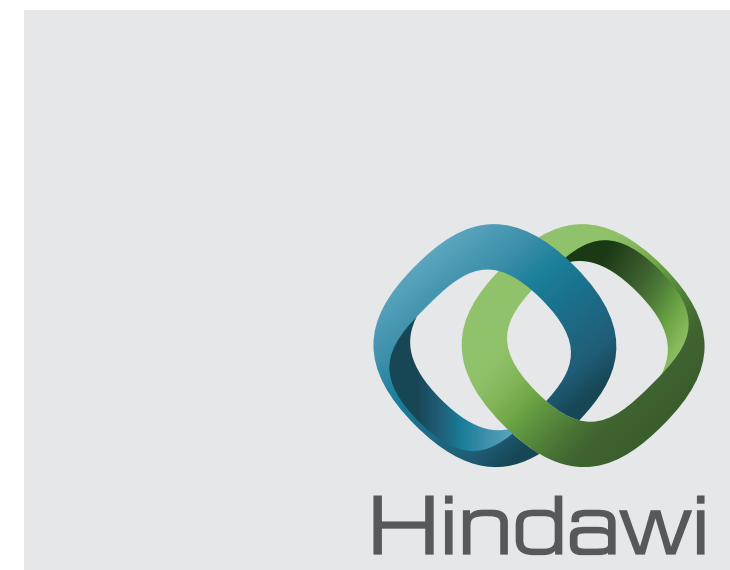

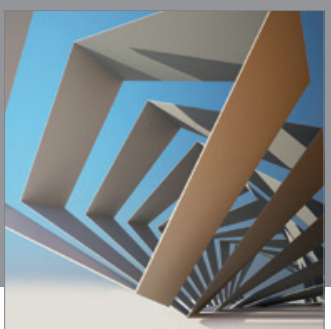

Rotating

Machinery
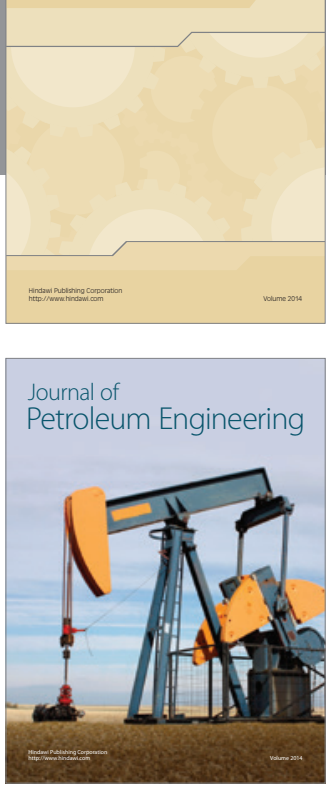

Journal of

Solar Energy
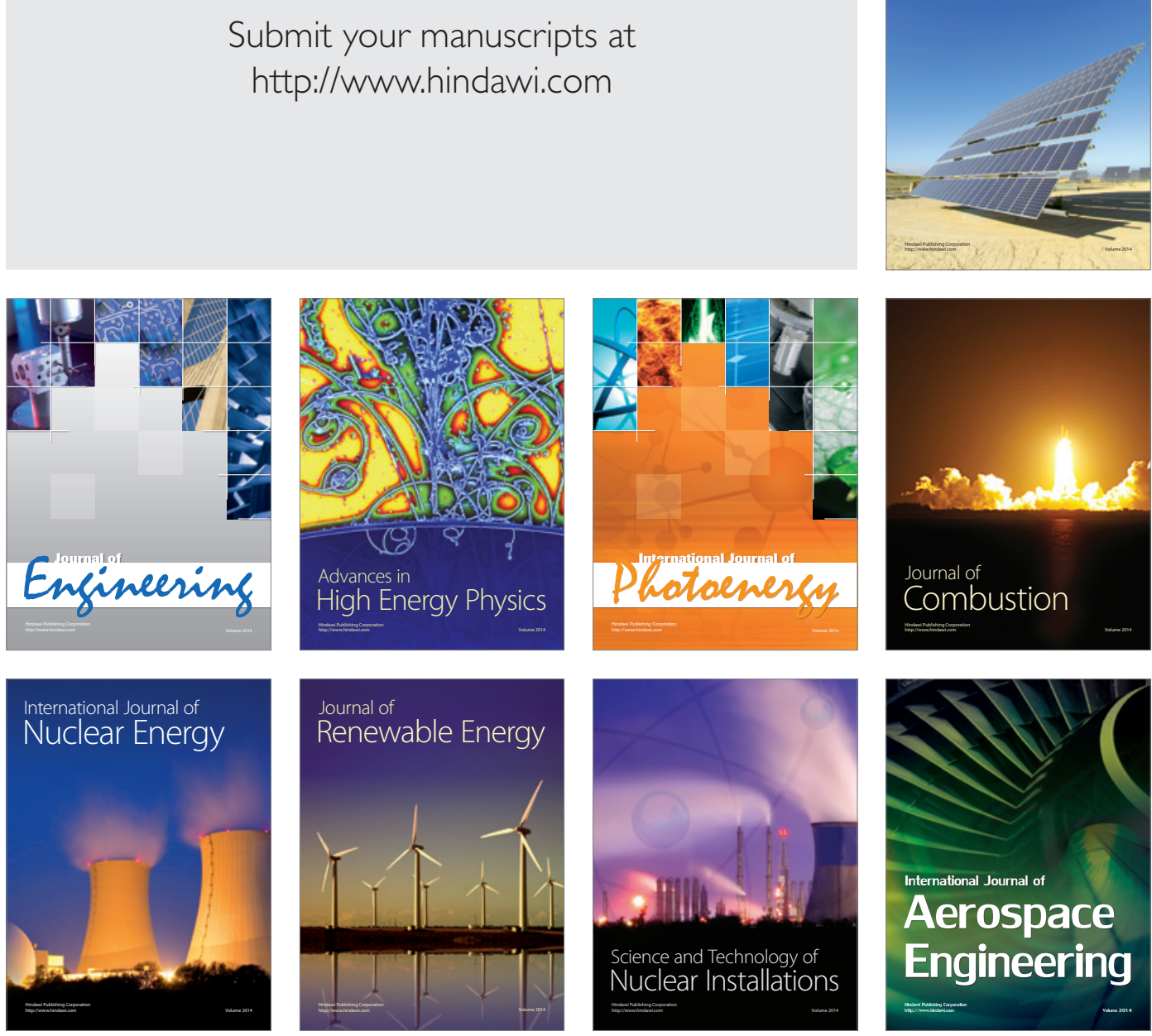